Article

\title{
Female Labour Force Participation: What Prevents Sustainable Development Goals from Being Realised in Iran?
}

\author{
Elham Taheri *(D), Fatma Güven Lisaniler (D) and Cem Payaslioğlu \\ Department of Economics, Eastern Mediterranean University, Famagusta 99450, North Cyprus; \\ fatma.guven@emu.edu.tr (F.G.L.); cem.payasli@emu.edu.tr (C.P.) \\ * Correspondence: elham.taheri@emu.edu.tr
}

Citation: Taheri, E.; Güven Lisaniler, F.; Payaslioğlu, C. Female Labour Force Participation: What Prevents Sustainable Development Goals from Being Realised in Iran? Sustainability 2021, 13, 11918. https://doi.org/ $10.3390 /$ su132111918

Academic Editors: Vasilii Erokhin, Tianming Gao and Andrei Jean Vasile

Received: 27 September 2021

Accepted: 25 October 2021

Published: 28 October 2021

Publisher's Note: MDPI stays neutral with regard to jurisdictional claims in published maps and institutional affiliations.

Copyright: (c) 2021 by the authors. Licensee MDPI, Basel, Switzerland. This article is an open access article distributed under the terms and conditions of the Creative Commons Attribution (CC BY) license (https:// creativecommons.org/licenses/by/ $4.0 /)$.

\begin{abstract}
Elimination of the gender gap in labour force participation has become one of the main challenges of achieving the U.N.'s Sustainable Development Goals (SDGs) in the 2030 Agenda for Sustainable Development. The rapid increase in university education and decrease in fertility rate in Iran over the past decades might affect the achievement of the SDGs. However, the country's female labour force participation (FLFP) rate stagnates at a superficial level. The stagnating FLFP rate is inconsistent with basic labour economics supply-side explanations while drawing attention to demand-side explanations, namely, female labour demand constraints, such as occupational segregation and labour market discrimination. This study empirically investigates the effect on FLFP of primary labour supply factors along with household conditions and gender norms and attitudes for 2 specific years: 2008 and 2018. The aim is to shed light on the causes of stagnation at the FLFP level by using the Household Expenditure and Income Survey conducted annually by the Statistical Center of Iran. The empirical findings suggest gender norms and attitudes towards working women and gendered division of work associated with family care as the driving forces of stagnation in FLFP in Iran.
\end{abstract}

Keywords: female labour force participation; Iran; gender norms; care work; sustainable development goals

\section{Introduction}

Women's economic empowerment and gender equality are among the main pillars of Sustainable Development Goals (SDGs) launched by the United Nations (U.N.) in the 2030 Agenda for Sustainable Development [1]. Women are considered a critical agent in eliminating poverty and having sustainable economic growth (SDG 1 and 8). Excluding them from social and economic activities causes problems for the following generations and the economy.

As anticipated by the third and fourth SDGs, which refer to healthy lives and equal opportunity in education, respectively, the rapid decline in fertility rates and the substantial expansion in female education were expected to boost female labour force participation (FLFP). However, FLFP levels and trends in some countries are seen to behave rather more diversely. Studies on female labour force participation levels and trends in developing countries are not homogenous. They found that while the FLFP rates are rising in Latin America, they are decreasing or stagnating in South Asia and only modestly improving in the Middle East [2,3]. These barriers are manifested by society's gender norm and noneconomic attitudes towards education and working women, gender division in household work, and inconsistency of women's education with the needs of the labour market.

This study traces the key determinants of FLFP through these barriers in the last decade to examine what factors limit SDGs' achievement.

Whereas the paper's framework would apply to many developing countries in the Middle East and North Africa, the study uses Iran's labour market as its focus. Women in 
these countries are trying to overcome political and social limitations. At the same time, different historical trajectories, cultural practices, and social fabrics are often unique to a country.

Over the past decades, Iran has gone through various social and cultural transformations. Many fundamental societal changes have taken place over the decade. There has been a significant increase in female education, an increase in the average age of marriage, an increase in the frequency of divorce [4], a rapid decrease in fertility rate, a reduction in average household size, freedom in choosing their spouse, and the possibility for women to file for divorce, which are a robust set of factors that have increased the participation of women in the political arena [5] (p. 594). These advances have been perused to open up opportunities for their entry into employment in educational fields.

According to the results of the World Values Survey in Iran, although a large share of respondents think that men make better political leaders and business executives than women, there is a significant decrease in the percentage of respondents who agree with these statements (from 78\% in 2005 to 59\% in 2017). The share of respondents agreeing that men make better business executives than women declined from $78.1 \%$ in 2005 to $49.5 \%$ in 2017. In addition, the share of respondents who agree to prioritise men when jobs are limited decreased from $83 \%$ to $69.6 \%$ [6,7]. Disaggregation of the respondents by sex shows that the proportion of women agreeing with these statements is lower than men by around $10 \%$ for all three statements. Additionally, the proportion of women respondents below age 29 who agree with these statements is much lower than older female respondents who agree with the above statements.

The disaggregation of the respondents by sex and level of education provides evidence that the stigma associated with being a working woman decreases as education levels increase for both sexes. The decline in the proportion of female respondents who agree with these male chauvinist statements over these 12 years has been twice as large as that of male respondents. At the same time, the share of respondents who agree that university education is more important for boys than girls decreased by almost $10 \%$ (from $55.4 \%$ to $46 \%$ ). All these shreds of evidence indicate the vast shifts from historical rigid social norms, and the gender gap in unpaid and care work is narrowing.

The study of the determinants of female participation undertaken in this article for Iran points to the plight of Iranian women who suffer the most under the country's current economic and political conditions. They are affected far worse than men by the consequences of political disputes, such as economic sanctions [8,9] and economic fluctuations, due to their disadvantageous position in society.

While the national literature has emphasised some factors, such as age, education, marital status, and the number of children, as limiting FLFP in Iran, we argue that gender norms and attitudes towards working women and gender division of family care tasks, while changing, are still the principal forces suppressing the rise in the FLFP level in Iran. Another noticeable gap in the empirical literature on FLFP in Iran is that most studies are based on cross-sectional variation rather than changes over time. From this standpoint, this study empirically investigates the effect on FLFP of basic labour supply factors along with household conditions and gender norms and attitudes for 2 specific years: 2008 and 2018. The aim is to shed light on the causes of Iran's relatively low FLFP level by using the country's Household Expenditure and Income Survey data covering a decade. The paper is organised as follows: The following section presents the theoretical framework and a review of the relevant literature. The third section provides a brief historical background pertinent to the female labour involvement in Iran. Data and the model of the empirical study are provided in the fourth section. Section 5 introduces the empirical findings. In the last section, the results are discussed, and possible entry points are suggested for achieving the SDGs as related to the full participation of women in the life of society in Iran by tackling the stagnating level of the FLFP. 


\section{Theoretical Framework and Related Literature}

The predominant classical economic model that analyses the female labour force participation decision, Becker's time allocation model [10], explains how rational individuals (man or woman) allocate their time between leisure and working outside the household to maximise their satisfaction. The model also describes how they allocate their "leisure time" within the household (for example, doing house chores, caring for their children). The model stresses the impact of age, female education, husband's income, other household income, marital status, and the number of children on FLFP [11-14]. According to the model, the difference between the education levels of women and men is associated with their labour market productivity, and their different tastes for market and home production shape their participation decision. Women's lower level of education constrains their labour market return; besides, they tend to have a stronger preference for home production than men. Thus, they decide not to join the labour force or even devote some hours when the family income (husband's wage income or other household income) is not enough to cover the household expenditures. An increase in female education increases their qualifications for the labour market and, thus, labour market returns, leading to a rise in FLFP.

Marriage and the presence of children increase the demand for home production. An increase in the husband's income or other household income tends to lower the participation of women in the labour market since they specialise in home production more than market production. Spending more time on home production limits the time devoted to market production, thus reducing female labour force participation.

In this model, the characteristics of a woman, such as age, marital status, number of children, household income other than wage income, and policies that influence the relative returns to market and home production (such as labour taxation or childcare provision), are the determinants influencing the participation decision. However, the model has one deficiency: it leaves out gender norms and attitudes as factors affecting (limiting) a woman's individual participation decisions.

Previous studies emphasised the supply-side explanation of FLFP in the MENA region. In examining the validity of the determinants of the time allocation model over time in MENA, extensive literature explains the low level of FLFP by controlling for educational level, marital status, age, and rural/urban differences [15-17]. Their findings emphasised that less educated married women living in rural areas have limited participation in the labour market. Another essential common factor that is wildly discussed in the studies related to MENA countries is the conservative gender norms in the region. Although some studies examined that the Islamic culture is attributed to low FLFP in MENA [18-20], the significant differences in the rates of female participation observed across the Islamic world, from Yemen to Malaysia, show their discussion's failure. Traditional norms and patriarchal culture seem to have more impact than Islam in lowering FLFP [21-24]. They argue that most of the variations in FLFP can be explained by a set of norms that emphasise the importance of the family and the domestic sphere in women's lives.

Although the earlier empirical studies on the Iranian labour market are limited and widely focused on macro level determinants of FLFP, female unemployment in particular $[25,26]$, they do shed light on the effect of fertility and female education levels on FLFP and employment. More recent empirical studies on female labour force participation determinants that rely on microdata provide evidence that supports Becker's time allocation model. They suggest female education, age, marriage, and the presence, number, and age of children as the main determinants of Iranian women's participation decision [26-30]. However, these later studies also go beyond the time allocation model and draw attention to the gender division of labour within the household. They argue that gender division of labour in the household increases the labour supply cost of women compared with men [28,31]. As a result, women tend not to participate in the labour force unless the labour market return is higher than the care cost [32,33]. Additionally, they argue that household members sharing home production also positively affect women's participation in the labour force [34]. 
Other than those mentioned above, there are also studies providing demand-side explanations. They mention the place of residence $[25,28]$ and the Iranian economy's dependence on oil exports [35] as female labour demand constraints suppress FLFP rates. They argue that the oil-dependent economy of Iran is a factor that constrains women's employment: it reduces female labour demand by crowding out female-intensive trades or sectors, leading to lower female participation as a result. These studies also argue that oil dependency decreases women's bargaining position by influencing family income and restricts women's labour market involvement $[2,33,35]$. The other demand constraint that they suggest is the added worker effect. During economic crises, a decrease in household income due to men's job losses necessitates an increase in women's involvement in the labour force [30,36].

Occupational gender segregation is another demand-side explanation suggested by these studies. They argue that high occupational segregation by gender affects FLFP negatively by influencing women's education choices, status, and income. Occupational gender segregation divides occupations as female and male occupations in conjunction with the gender wage gap, diminishes women's labour market prospects, and further enhances the crowding-out effect [28,30].

The literature on gender and social change in Iran stresses that, besides the basic labour supply factors, gender norms and attitudes towards women in society are rather important factors shaping women's labour force participation decision [34,37].

All of the above reviewed empirical studies on determinants of FLFP in Iran shed light on some factors affecting female labour force participation. However, they do not offer any insight into the impact of gender norms, attitudes towards working women, and persistent traditional gender roles besides classical determinants of FLFP. Changing attitudes towards women's position in the family and society after the Islamic Revolution started moderately after the Iran-Iraq War. After 2008, plenty of women's movements have increased the awareness of many Iranians about discrimination in marriage, divorce, custody, inheritance law, and economic and political rights. As a result, Iranian society went through enormous cultural, social, economic, and political changes between these 2 years. Thus, this paper aims to capture the impact of these changes by investigating and comparing the determinants of FLFP in Iran in 2008 and 2018.

Before going further, it will be helpful to provide a brief historical background relevant to female labour market involvement in Iran and an assessment of the position of Iranian women in the labour market.

\section{The Position of Women in the Labour Market in Contemporary Iran}

In the 1960s and 1970s (i.e., before the Islamic Revolution), Iran entered into the global economy and new local industries. This situation is accompanied by Pahlavi's "White Revolution" (introducing a significant change in the Family Protection Law and providing welfare and educational services for women and modernising Iran). As a result of these changes, there was an expansion of employment opportunities for women. At this time, Iran was entering into the global economy, and there was an emergence in the country of new local industries that accompanied Pahlavi's "White Revolution." The modernisation of Iran brought with it a significant change in the Family Protection Law, which provided welfare and educational services for women. Although the formal sector was male dominated, the "White Revolution" opened new women's employment doors. More educated women were finding employment opportunities in the education and health sectors. Less educated women benefited from job opportunities in traditional craftwork as rug and handicraft makers in rural areas or as sellers in urban areas. The majority of rural women continued as unpaid family workers in family farms or rug-making businesses. By the mid-1970s, the FLFP rate had reached 12\% from 9.5\% in 1956 [37].

Since the Islamic Revolution in 1979, the role of women in public places and the pattern of their economic activities have constituted an issue of major concern to politicians. Division of labour and the relationship between men and women continue to be legally 
determined by the Iranian Civil Code based on Sharia Law, which puts women in an unfavourable dependent position. Men have privileges in the labour market, and economic activities are men's prerogative. In other words, by law, men have authority over women in both the public and private spheres of life because they are heads of the household and the sole breadwinners for the family.

Although there were not that many employment opportunities available for women even before the revolution, the Islamisation policies that emphasised the traditional gender role of women as wives and mothers and compelled them to wear a veil in the public workplace forced a large group of elite and middle-class women into leaving their jobs [38]. Simultaneously, lower-income women lost their jobs because of the deceleration of economic growth.

Although Islamisation policies harm women's labour market involvement, sex segregation in schools because of Islamisation of the education system increases access to education for women. Sex-segregated schools also increased the number of women in the public sphere as teachers and students by creating an acceptable environment for the conservative culture [39].

\section{Education Reform, Family Planning, and FLFP}

Following the 1978 revolution, education for women was strongly advocated by Iran's leaders. The country took deliberate steps towards achieving the fourth goal of sustainable development to close the gender gap in education. The adult female literacy rate increased from $56.2 \%$ in 1990 to $80.8 \%$ in 2018 . The increase in rural areas, from $1.2 \%$ to $72.8 \%$, is even more striking. A rise in women's literacy rate was not the only improvement in female education. In 1990, women made up 30\% of university graduates, and this ratio increased to more than $50 \%$ in 2018 (SCI, 2018).

The Iranian national family planning programs between 1986 and 2000 caused a 64\% decline in the total fertility rate from $6.42 \%$ to $1.72 \%$. This effective family planning program allowed Iran to achieve several targets within SDG3, such as infant and U5 mortality rate, maternal mortality ratio, safe delivery, and protecting the health and nutrition of children. As a result, Iran could close the education gap and save the lives of countless women and children.

However, despite the improvement in health indicators and literacy skills or qualifications, such as a high school or university diploma, women's progress in gaining access to the labour market has been slow. The FLFP rate increased from $10.1 \%$ in 1990 to just $16 \%$ in 2018.

Higher education has helped women liberate themselves from family and society restrictions and increased their bargaining power in marriage and the marriage market [30]. Nevertheless, it has not served women well in the labour market. From 2008 to 2018, the rate of female employment has remained far below that of men. During this decade, the employment rate of women has improved by $5.8 \%$, whereas the male employment rate has increased by 15.1 percentage points. On the other hand, finding a job is still much easier for men than for women. Female unemployment rates are always twice as high as male unemployment rates. The high female unemployment rate also reflects an increasing number of women seeking jobs in the labour market [37,40].

In Iran, economic growth and employment have had a puzzling relationship over the years. Despite the steady growth in real non-oil GDP between 2008 and 2018, net employment has remained almost stagnant. In other words, the relatively high non-oil growth could not provide jobs in the labour market. In the meantime, two important factors have had an impact on Iran's economic growth and labour market outcomes. First, in 2011 the subsidy reform in the domestic petroleum sector reduced the significant inefficiencies and the misallocation of resources in the economy. This allowed greater sales of petroleum abroad at a time of record-high oil prices. This stimulated GDP growth. Second, the imposition of severe sanctions in mid-2012 caused high inflation and a sharp decline in economic activities and FDI inflow. The subsequent contraction in businesses further 
constrained job creation. The employment of women seemed to suffer more from the severe sanctions. While the financial sector, which is primarily male dominated, expanded after the imposition of sanctions, the service sector, where women mostly work, shrank.

FLFP in Iran is very sensitive to economic structural changes due to high and persistent sectoral and occupational gender segregation in employment. The findings of previous studies on female unemployment show that economic structure and occupational gender segregation are the main factors blocking women's access to the labour market [41-44]. Along with occupational segregation, other social factors restrict the jobs deemed appropriate for women. Reservation working conditions (acceptable working environment) and refusing to work in jobs they consider beneath them (reservation prestige affect) have an impact on women's distribution among occupational categories [45]. These social norms are evolving in Iran, but their slow adjustment has restrained the speed at which the FLFP has been able to increase. Table 1 depicts occupational distribution by broad occupational categories and gender in 2008 and 2018.

Table 1. Major occupations by gender (\%)-2008 and 2018.

\begin{tabular}{lcccccc}
\hline 9 Broad Occupational Categories & \multicolumn{2}{c}{ Total } & \multicolumn{2}{c}{ Male } & \multicolumn{2}{c}{ Female } \\
\hline & 2008 & 2018 & 2008 & 2018 & 2008 & 2018 \\
\hline 1. Legislators, Senior Officials, and Managers & 2.8 & 3 & 3 & 2.9 & 2 & 3.1 \\
2. Professionals & 7.9 & 10.1 & 5.4 & 6.7 & 18.7 & 25.2 \\
3. Technicians and Associate Professionals & 4.6 & 5.7 & 4.7 & 5.2 & 4.3 & 7.6 \\
4. Clerical and Administrative Workers & 4.8 & 3.8 & 4.4 & 3.3 & 6.3 & 5.8 \\
5. Service Workers and Shop and Market & 12.7 & 15.9 & 13.9 & 16.6 & 7.5 & 12.5 \\
Sales Workers & & & & & & \\
6. Skilled Workers in the Agriculture, Forestry, & 18.9 & 13.8 & 16.9 & 13.2 & 27.9 & 16.3 \\
and Fisheries Sector & 19.7 & 19.5 & 18.5 & 19.3 & 25.2 & 20.7 \\
7. Crafts and Related Trade Workers & 11.3 & 12.4 & 13.7 & 14.8 & 0.6 & 1.4 \\
8. Machine Operators, Assemblers, and Drivers & 14.9 & 13.7 & 16.6 & 15.1 & 7.3 & 7.2 \\
9. Labourers & 100 & 100 & 100 & 100 & 100 & 100 \\
Total & & & & & &
\end{tabular}

The distribution of women across occupational categories changed between 2008 and 2018. More than two-thirds of employed women were in three occupational categories in both years but with differing proportions: (1) professionals, (2) crafts and related trade workers, and (3) agricultural workers (Table 1). However, the occupational distribution of employed men shows a more balanced distribution among occupational categories. The change in women's distribution from 2008 to 2018 is associated with the decline in agricultural employment and the increase in the supply of educated women. In 2008, skilled agricultural workers constituted a large share of women's employment (27.9\%). A noticeable rise in female education levels meant that more women were seeking and getting better jobs in the formal sector. The result was an increase in the proportion of women in the category of professionals, which became the largest category in which women worked in $2018(25.2 \%)$.

The concentration of women in a limited number of occupations negatively affected women's income and status. It resulted in many joining the ranks of the unemployed or dropping out of the official labour force due to the crowding-out effect and the discouraged worker effect $[46,47]$.

The relative shortage of high-skilled job opportunities in the labour market led to better-educated women taking up lower-skilled jobs. Thus, pushing less educated women out of the job market is reflected in the distribution of women in occupational categories.

\section{Data, Methodology, and the Model of the Empirical Study}

This section presents details about the data source and the model used to conduct the empirical study. The Household Expenditure and Income Surveys (HEISs) have been 
conducted annually by the Statistical Center of Iran since 1963 in rural areas and since 1968 in urban areas. The surveys include information concerning demographics, assets, expenditure, and income. These surveys are nationally representative samples, with a new sample drawn from the population each year. The present study uses the crosssectional data set for two specific years-2008 and 2018 - and it is not a panel data set that traces individual households and individuals over time. The survey data were obtained electronically from the official website of the Statistical Center of Iran.

The 2008 and 2018 survey reports provide data for 22,666 and 39,894 households, respectively. Although HEIS includes data for all ages, we constructed a separate data set for ages 15 to 60 years (the latter is the full-benefit retirement age in Iran's social insurance system run by its Social Security Organisation). The summary statistics of the dependent and independent variables used in the econometric model are provided in Table 2. The descriptive statistics show that while the Iranian female labour force expanded by $1 \%$, the number of those who dropped out of the labour market declined by $1 \%$ too. There are also differences in observed characteristics across time.

Table 2. Microlevel descriptive statistic of women in sample data (\%) by variables in 2008-2018.

\begin{tabular}{|c|c|c|c|}
\hline Variables & 2008 & 2018 & $\Delta$ \\
\hline Total observation (number) & 42,955 & 43,481 & 526 \\
\hline Labour force & 18.94 & 20.02 & 1.08 \\
\hline Out of LF & 81.06 & 79.98 & -1.08 \\
\hline \multicolumn{4}{|l|}{ Age } \\
\hline $15-20$ & 23.37 & 13.06 & -10.31 \\
\hline $21-30$ & 30.08 & 27.08 & -3 \\
\hline $31-40$ & 20.36 & 25.37 & 5.01 \\
\hline $41-50$ & 15.43 & 19.56 & 4.13 \\
\hline $51-60$ & 10.76 & 14.93 & 4.17 \\
\hline \multicolumn{4}{|l|}{ Education } \\
\hline Literate without diploma & 3.02 & 5.26 & 2.24 \\
\hline Primary school & 38.64 & 30.71 & -7.93 \\
\hline Junior high school & 46.01 & 23.47 & -22.54 \\
\hline 12 years diploma & 1.21 & 23.02 & 21.81 \\
\hline University level & 11.12 & 17.54 & 6.42 \\
\hline \multicolumn{4}{|l|}{ Marital status } \\
\hline Married & 62.19 & 68.09 & 5.9 \\
\hline Single/divorce/widow(er) & 50.28 & 31.91 & -18.37 \\
\hline \multicolumn{4}{|l|}{ Area of residence } \\
\hline Urban & 49.72 & 51.46 & 1.74 \\
\hline Rural & 50.28 & 48.54 & -1.74 \\
\hline \multicolumn{4}{|l|}{ Number of children $=<6$} \\
\hline No child & 76.17 & 75.88 & -0.29 \\
\hline 1-2 children & 22.18 & 23.67 & 1.49 \\
\hline More than 2 & 1.66 & 0.46 & -1.2 \\
\hline \multicolumn{4}{|l|}{ Number of children $=>18$ female } \\
\hline No child & 82.55 & 87.00 & 4.45 \\
\hline 1-2 children & 15.56 & 12.41 & -3.15 \\
\hline More than 2 & 1.88 & 0.56 & -1.32 \\
\hline \multicolumn{4}{|l|}{ Number of children $=>18$ male } \\
\hline No child & 78.56 & 80.50 & 1.94 \\
\hline 1-2 children & 18.01 & 18.26 & 0.25 \\
\hline More than 2 & 3.40 & 1.23 & -2.17 \\
\hline \multicolumn{4}{|l|}{ Number of members above 60} \\
\hline No member & 97.60 & 99.05 & 1.45 \\
\hline 1 member & 2.26 & 0.86 & -1.4 \\
\hline 2 members & 0.14 & 0.09 & -0.05 \\
\hline \multicolumn{4}{|l|}{ Husband's education } \\
\hline $1-12$ years of schooling & 87.85 & 86.80 & -1.05 \\
\hline University level & 12.15 & 13.20 & 1.05 \\
\hline \multicolumn{4}{|l|}{ Family structure } \\
\hline Nuclear & 80.13 & 78.02 & -2.11 \\
\hline Extended & 19.87 & 21.98 & 2.11 \\
\hline Average husband's income + nonlabour income & 9.758 & 2.0288 & -7.7292 \\
\hline
\end{tabular}




\subsection{Analytic Strategy}

In the study of FLFP, where the variables are explained with binary or categorical values, the linear probability model is suggested, and it is easy to interpret. However, the linear probability model is suffering from some issues: (i) It can predict probability that is negative or larger than one. (ii) A unit change in a regressor can induce an increase or decrease in probability larger than 1 . (iii) A change in one unit in one regressor has a constant effect. (iv) The true relationship between a binary outcome and a continuous explanatory variable is inherently nonlinear. This means that the functional form of the LPM is generally not correctly specified, which can lead to biased estimates of some parameters of interest. The insufficiency of the linear probability model suggests that nonlinear specification may be more appropriate. Therefore, the logit model used in the empirical analysis identifies factors affecting female labour force participation decisions. The primary advantage of the logit model is that the probability of occurrence increases with " $x$ " but never steps outside the $0-1$ interval. The relationship between the variables is nonlinear.

Generally, the logistic regression model calculates the probability of one of two categories in the data set. For the logit model, $P i$ is determined based on the logit distribution:

$$
p_{i=F\left(X_{i}^{\prime}, a\right)=\frac{\exp \left(X_{i}^{\prime}, a\right)}{1+\exp \left(X_{i}^{\prime}, a\right)}}
$$

where $P i$ denotes the probability that individual $i$ participates in the labour force, $a$ is a regression coefficient, and $X_{i}^{\prime}$ is a vector of individual characteristics containing the following variables: (1) demographic and human capital characteristics, such as age, education, and area of residence; (2) gender division of care work (unpaid work) measured by marriage, number of children below age 6 , and number of elderly in the household; (3) gender norms and attitudes measured by husband's education level and family type; and (4) husband's income, other non-labour income, and number of adult children in the household used to measure household conditions. The model parameters are estimated through the method of maximum likelihood.

\subsection{Variables}

The predicted variable, female labour force participation (FLFP), is a dummy variable equal to 1 if the individual is in the labour force and 0 otherwise. In line with the theoretical model, independent variables are categorised into four groups:

\subsubsection{Demographic Variables}

The age of the respondent is used to measure the impact of life cycle changes on FLFP, and it is transformed into five categorical variables. Previous studies portray an inverted U-shaped relationship between age and participation [41]. The region measures urban-rural differences in FLFP. The place of residence is included as a dummy variable, equal to 1 when the individual resides in an urban area and 0 when an individual resides in a rural area, to reflect job opportunities and differences between regions.

Education is used to control the labour market qualifications. This variable is transformed into categorical variables showing women's level of education (diploma): $1=$ at least completed primary school, 2 = at least completed junior high school, $3=$ at least completed 12 years of schooling (high school diploma), and $4=$ at least completed some university degree course.

\subsubsection{Gender Division of Care Task}

Marital status, the number of children below age 6 (school age), and the number of household members above 60 measure the impact of care tasks on FLFP. Because the number of divorced or widowed persons was less than 100 in the observation, this variable is transformed into a dummy variable: $1=$ married and $0=$ single/divorced $/$ widow(er). 
The effect of marital status on FLFP shows the impact of the gender division of care tasks in the household on the FLFP level. It might also capture the change in social attitudes towards working women and the hierarchy of power between the couple.

\subsubsection{Gender Norms and Attitudes}

HEIS data in Iran are limited in finding a variable that can capture social norms and attitudes. According to the results of the World Values Survey in Iran (2017-2020), the disaggregation of respondents by sex and level of education with those survey equations measuring the perception of society of working women, such as "men make better business executives than women", "being a housewife is just as fulfilling", "preschool child suffers from working mother", and belief in "gender equality in job" indicates that the stigma associated with being a working woman decreases as men's education increases.

The extant literature also suggests using the "husband's" education as a measure of gender norms and attitudes towards working women and the level of traditionalism. It is argued that in countries with stronger social stigma associated with being a working woman, the relationship between the husband's education level and FLFP is negative, particularly among the more educated groups [2,22]. The partner's education level is measured in two categories: $1-12$ years of schooling $=0$, university level $=1$.

The second variable to estimate the effect of gender norms and attitudes is the family structure (extended or nuclear family). We expected that traditional households were more often extended. Women living in extended families may have less motivation to enter the labour market due to the internalised traditional family roles. It may be that the husband or other family members have a strong voice in participation decisions [22]. Family structure is a dummy variable equal to 0 when the family members are more than the couple and their children (extended) and 1 when it is a nuclear family.

\subsubsection{Household Income}

In line with the neoclassical theory of labour supply, household condition (husband's income + non-labour income) is added to the model as a variable to measure the impact of household financial condition on female labour force participation [1]. As a proxy for the potential household member who can be available in the labour force and generate income, the numbers of adult female and male members (above age 18) are included in this model [18].

\section{Empirical Findings}

The estimation result generated by Equation (1) is reported in Table 3. The findings reveal that although there has been no significant rise in FLFP in the past decade in Iran, change in social norms and attitudes towards women's status in society and the household is undeniable. The effect of these changes appears in the sign and size of coefficients.

The findings show that the coefficients of age categories are significant across both periods but with a relatively smaller coefficient size for 2018. Age tends to increase the chances of a woman's participation in the labour market; this increase is steady until age 51-60. It may be a consequence of the sharp decline in fertility and the increasing number of divorced women. Women belonging to the 15- to 20-year age group are less likely to participate in the labour market. This may reflect the shifts in attitudes towards girls' university education. WVS data show that 44\% of the respondents in 2005 and 52\% in 2017 disagreed that university education is more important for boys than girls. Middleaged postrevolutionary women baby boomers (early 1980s) are more likely to participate in the labour market.

The average age at which women give birth in Iran ranges between 28 and 30 in urban areas and between 23 and 28 in rural areas. Thus, when women get to their mid-30s and mid-40s, their children are of school age. This allows such women the flexibility of time towards market production. Furthermore, families need more resources to invest in the education of children. Here, the age indicator does not depict the inverted-U relationship for both years, 2008 and 2018. 
Table 3. Logistic models of women's LFP.

\begin{tabular}{|c|c|c|}
\hline VARIABLES & 2008 & 2018 \\
\hline Dependent Variable: FLFP & Coefficients & Coefficients \\
\hline \multicolumn{3}{|l|}{ Demographic and human capital variables } \\
\hline \multicolumn{3}{|l|}{ Age (base: 15-20) } \\
\hline $21-30$ & $\begin{array}{c}1.095^{* * *} \\
(0.206)\end{array}$ & $\begin{array}{l}0.543 * \\
(0.318)\end{array}$ \\
\hline $31-40$ & $\begin{array}{c}1.765^{* * *} \\
(0.204)\end{array}$ & $\begin{array}{c}0.962^{* * *} \\
(0.318)\end{array}$ \\
\hline $41-50$ & $\begin{array}{c}2.310^{* * *} \\
(0.207)\end{array}$ & $\begin{array}{c}1.412^{* * *} \\
(0.318)\end{array}$ \\
\hline $51-60$ & $\begin{array}{c}2.714^{* * * *} \\
(0.211)\end{array}$ & $\begin{array}{c}1.710 * * * \\
(0.321)\end{array}$ \\
\hline \multicolumn{3}{|l|}{ Education (base: literate without diploma) } \\
\hline Primary school & $\begin{array}{c}0.888^{* * *} \\
(0.296)\end{array}$ & $\begin{array}{l}0.566^{* * *} \\
(0.0854)\end{array}$ \\
\hline Junior high school & $\begin{array}{c}0.668^{* *} \\
(0.298)\end{array}$ & $\begin{array}{c}-0.0248 \\
(0.101)\end{array}$ \\
\hline 12 years diploma & $\begin{array}{c}3.315^{* * *} \\
(0.367)\end{array}$ & $\begin{array}{c}0.155 \\
(0.106)\end{array}$ \\
\hline University & $\begin{array}{c}3.399 * * * \\
(0.306)\end{array}$ & $\begin{array}{c}1.725 * * * \\
(0.116)\end{array}$ \\
\hline \multicolumn{3}{|l|}{ Area of residence (base: rural) } \\
\hline Urban & $\begin{array}{c}-1.844 * * * \\
(0.0471)\end{array}$ & $\begin{array}{c}-1.618 * * * \\
(0.0567)\end{array}$ \\
\hline \multicolumn{3}{|l|}{ Gender role variables } \\
\hline Married & $\begin{array}{c}-0.497^{* * *} \\
(0.108)\end{array}$ & $\begin{array}{c}0.730 * * * \\
(0.101)\end{array}$ \\
\hline Number of children $=<6$ & $\begin{array}{c}-0.218^{* * *} \\
(0.0280)\end{array}$ & $\begin{array}{c}-0.174^{* * *} \\
(0.0443)\end{array}$ \\
\hline Number of household members $>60$ & $\begin{array}{c}-0.721 * * * \\
(0.177)\end{array}$ & $\begin{array}{l}-0.385 \\
(0.297)\end{array}$ \\
\hline \multicolumn{3}{|l|}{ Social and cultural values variables } \\
\hline University degree & $\begin{array}{c}0.0077 \\
(0.0654)\end{array}$ & $\begin{array}{l}0.378^{* * *} \\
(0.0794)\end{array}$ \\
\hline \multicolumn{3}{|l|}{ Family type (base: extended family) } \\
\hline Nuclear family & $\begin{array}{l}0.364^{* * *} \\
(0.0591)\end{array}$ & $\begin{array}{l}0.639^{* * *} \\
(0.0653)\end{array}$ \\
\hline \multicolumn{3}{|l|}{ Household financial status variable } \\
\hline Husband's income + non-labour income & $\begin{array}{c}-0.00618 * \\
(0.00324)\end{array}$ & $\begin{array}{l}0.188^{* * *} \\
(0.00339)\end{array}$ \\
\hline Number of female children $>18$ & $\begin{array}{c}-0.333^{* * * *} \\
(0.0443)\end{array}$ & $\begin{array}{c}0.0863 \\
(0.0696)\end{array}$ \\
\hline Number of male children $>18$ & $\begin{array}{c}-0.424^{* * *} \\
(0.0383)\end{array}$ & $\begin{array}{l}-0.0830 \\
(0.0637)\end{array}$ \\
\hline Constant & $\begin{array}{c}-2.067^{* * *} \\
(0.379)\end{array}$ & $\begin{array}{c}-3.414^{* * *} \\
(0.347)\end{array}$ \\
\hline Observations & 18,594 & 22,478 \\
\hline
\end{tabular}

Standard errors in parentheses. ${ }^{* * *} p<0.01,{ }^{* *} p<0.05,{ }^{*} p<0.1$.

In line with the FLFP literature in MENA countries and Iran, women's university education continued to play a significant role in determining FLFP in 2018. Although the coefficient of university education implies that education is a strong determinant of FLFP, our findings and coefficient size show that the importance of this factor diminished in comparison with 2008. A woman with a university degree, all else being equal, is predicted as having a $79 \%$ chance of participating in the labour market (probability $=1 /(1+\exp (-\mathrm{x}))$ $=1 /(1+\exp (-1.332))$ in 2008 . However, this probability decreased up to $15 \%$ in 2018 . 
The reduction in the positive effect of education on FLFP is large. It almost completely cancels the effect of a modest reduction in the social stigma associated with being a working woman, as WVS data suggest.

Residence in urban areas appeared to have reduced a female's probability of participation in both 2008 and 2018. Esfahani and Shajari [25] and Majbouri [28] also found that residing in rural areas marginally increases the chances of FLFP. If a woman has a university education and lives in an urban area, these two effects almost cancelled each other out in 2018. In contrast, residence in rural areas increases women's involvement in the labour force, which is likely the result of having greater access to extended families for childcare. Additionally, women may have a lower level of reservation prestige for taking jobs in rural areas because many businesses employing women tend to be family or acquaintance based. Transportation costs are often modest in rural areas.

Many educated urban women choose to remain at home. High childcare costs and transportation costs increase the reservation wage of urban women. In some areas, the labour market environment is not very palatable due to sexual harassment and the availability of few high-paid jobs.

The findings of previous studies of Iran suggest a strong negative relationship between marital status and women's labour market involvement. Although in 2008 results marriage appears to be in the same line with the literature, the effect of marriage is significantly positive in 2018. This may be due to a decrease in the social stigma associated with being a working married woman or changing household conditions (changes in family income). By 2018, the economic hardship brought about by the severe sanctions imposed on Iran had resulted in married women in Iran being pushed to work to help the family to survive.

There is an inverse relationship between FLFP and the number of children younger than 6 in 2008 and 2018, although the coefficient is smaller in 2018. In alignment with our results, Esfahani [25] also found the negative impact of a child's age on FLFP mitigated when children grow above 6 years of age. A larger number of elderly household members served to decrease women's labour market involvement in 2008, but by 2018, this effect was insignificant but still negative in sign. Overall, an increase in the number of children below age 6 and the number of elderly push up household care costs and restrict women's labour market involvement. In our case, although the increasing care cost of children restricts women's participation in the labour force, this restrictive effect is weaker in 2018 than in 2008.

The husband's education level is included in the model to capture gender norms and attitudes towards women. The WVS data offer evidence that supports the finding that gender norms and attitudes towards women are changing, which in turn helps to explain the puzzling effect of marriage and care costs. The estimates show that women with more educated husbands are more likely to participate in the labour force in both years, but only the 2018 estimate is significant. Thus, according to the finding, having a working wife is not a problem, which negatively reflects on the ability of an educated man to be able to provide for the family. Disaggregated WVS data by education level and sex also suggest a negative relationship between the husband's education level and the social stigma of having a wife who is a working woman. As the education level of men increases, the share of respondents who agree with the statement "When jobs are scarce, men should have the priority" decreases in both survey years, 2005 and 2017. The share of better-educated men who agree with the above statement was the lowest ever in both the 2005 and 2017 surveys. Analysis of married respondents also reveals that as the education level increases, the proportion of respondents who agree with the above statement decreases.

Women's labour market attachment is closely related to household conditions, especially in developing countries. Improvement in the husband's income (or other household income) or increase in the number of income earners in the household tends to decrease women's labour market involvement. The findings of the present study support this relationship. Additionally, the relationship is even stronger in 2018. 
The number of additional potential income earners, the number of male and female children above age 18 in the household, is not significant in 2018. This may be a result of increased years of schooling for young children and high youth unemployment. Hence, there is no increase in the number of income earners in the household. Our findings are in the opposite direction with Majbouri's [29] results. His studies indicate that the presence of an adult female in the household increases the likelihood of women working by about $3 \%$. In contrast, the presence of adult males has a negative impact on FLFP.

To summarise, empirical findings for 2 different years, 2008 and 2018, provide evidence that although the shift in gender norms and attitudes towards a more gender-equal society in Iran did not increase the FLFP rate, it affects the relationship and size of the FLFP's determinants.

\section{Discussion, Conclusions, and Policy Suggestions}

Since 2008, there has been a significant improvement in closing the education gap (SDG4) between men and women and improving society's health conditions (SDG3), particularly those of women in Iran. These are two essential United Nations Sustainable Development Goals to empower women. However, despite the satisfactory development of the factors that are key determinants of FLFP, the level of participation of females in the labour force has continued to lag. Women's presence as representatives in public institutions also continues to be relatively low. The progress in FLFP is a matter of social and economic justice (SDG5) and positively contributes to the sustainable economic growth of a country (SDG8). The major challenges to achieving these goals in Iran remain solid, and they improve moderately and insufficiently to attain sustainable goals.

Most Iranian women do not have a solid attachment to the labour force. This can be observed in the relationship between female education level and FLFP. Female education and labour force participation often have a U-shaped relationship: FLFP is higher in lower levels of education, lower in middle-level education, and higher again in the highest-level (university) education [1]. This relationship was not U-shaped in 2008 in Iran, but it turned U-shaped in 2018. The 2018 estimations show that education level is not a determinant of FLFP, except for the lowest (primary school) and the highest (tertiary) education levels. The female education and FLFP relationship acquired a shallow U-shape, reflecting the decrease in primary and tertiary education coefficient size.

Age has continued to be the determinant of female participation both in 2008 and 2018 . It also reflects the longer stay of women in education and the increase in the average age at which women give birth. By 2018, the decline in incomes in Iran certainly encouraged women to seek employment and overcome social barriers to maintain the level of household consumption that had previously been the norm for the family.

The estimations of the variables used to capture the effect of gender norms and attitudes towards working women and the gender division of care work depict the nature of gender relations in the Iranian labour market. They reveal the change in gender relations in the 10 years between 2008 and 2018.

Being married women, all else being equal, is predicted as reducing a $7 \%$ chance of participating in the labour market (probability $=1 /(1+\exp (-2.564))$ in 2008 . However, this probability increased women's involvement in the labour force in 2018 by $6 \%$. It is hard to jump to the conclusion that the gender division of care work has shifted towards a more gender-balanced division. Still, this result reflects the change in a woman's role in the family, and therefore in society, as a care provider, which shapes women's level and type of labour market involvement.

In addition, the number of elderly in the household was no longer a restriction on women's participation in the labour force. The number of children below age 6 was still a significantly negative determinant of women's involvement but became less effective (smaller coefficient size).

The variable used to capture gender norms and attitudes towards working women, the husband's education level, provides interesting evidence. It increased the probability of 
being in the labour force by $4 \%$ in 2018 . This result points to a reduction in the strength of the social stigma associated with being a working woman. WVS data also provide evidence supporting this finding.

It is possible to conclude that although the social stigma associated with being a working woman, married or not, is losing its strength, the caregiver role of women is pervasive and persistent. The explanation of this situation could be that women may also be considering their well-being when making a choice. Thinking of their well-being, women may decide not to participate in the labour force to avoid the double burden of paid and unpaid work. The estimated relationship between the type of family and FLFP shows that women living in nuclear families are more likely to participate in the labour force than women in extended families. Women in nuclear families may have the chance to have less care work, but this is not possible in an extended family where there is elderly adult to be cared.

In addition, due to the limited return of the jobs deemed appropriate for women according to gender norms, women, better-educated women in particular, tend to choose not to participate.

The number of additional potential income earners, the number of male and female children above age 18 in the household, was not significant in 2018. This may be a result of increased years of schooling for young children and high youth unemployment. Hence, there is no increase in the number of income earners in the household.

To summarise, empirical findings for two different years, 2008 and 2018, provide evidence that gender norms and attitudes towards women are in a transition in Iran. Despite the shift in gender norms and attitudes towards a more gender-equal society, Iran's gender regime is neo-patriarchal due to the political system and the government's development strategies. That causes the FLFP rate to remain stagnant at a very low level.

Acknowledging the large and expanding informal economy in Iran [38], the large female employment share in informal employment [48,49], and differences in the driving forces of FLFP, it is possible to suggest gender norms and attitudes towards women as the main determinants of women's employment in the economy.

\subsection{Policy Suggestions/Entry Points}

There are possible and proven actions to create economic opportunities for women and accelerate progress towards achieving SDGs. While the concept of gender equality and government responsibility towards it is universal, the effectiveness of solutions differs across countries based on their legal, cultural, institutional, and development levels. Some of these solutions are easy to implement and cost-effective, but new resources and effective leadership are needed for many other interventions.

This study has focused on improving some primary drivers to expand women's economic empowerment, given the range of possible suggestions.

\subsubsection{Promotion of Entrepreneurship}

As mentioned earlier, women's enrolment in higher education had significant growth in recent years. Since the Iranian labour market cannot provide enough employment opportunities to the majority of these educated women, women's entrepreneurship can be considered one factor contributing to women's increasing participation. Despite all improvements in the last decade, entrepreneurs in Iran, regardless of gender, face many challenges, such as government domination and intervention, sanctions, restricted trade policy, and business laws. However, women, due to gender inequality and social stereotype, tend to face more challenges. The entrepreneurial activity rate of women in Iran is 9.9 versus the corresponding rate of 16.2 for men [50]. Specific policies, such as streamlining the process of obtaining permits and reducing its costs, gaining better access to credit, reducing government controls over credit allocation, and reducing uncertainty as well as change in social stereotype, broad network, and family support would encourage and facilitate entrepreneurship among educated women. 
Fortunately, since 2017, a program to support the development and sustainable employment in the rural area has been implemented in Iran, providing better access to credits and helping many rural women to be entrepreneurs in agriculture and non-agriculture parts. This program helps to reduce female unemployment rate in rural areas compared with urban women (7.8 per cent vs. 21 per cent, respectively, SCI, 2018).

\subsubsection{Tackling the Gender Norms and Attitudes}

Suggesting gender norms and attitudes towards women as the causes of the stagnating FLFP level might look like entering a dead-end street or turning policy suggestions into a policy issue. However, it provides entry points to tackle the stagnating FLFP level and further transform gender norms and attitudes towards women.

Any significant change in gender norms and attitudes will take a long time, but until then, there may be a substantial scope to make daily public spaces more women friendly to ease practical constraints on their daily lives. Challenging the gender division of public places and creating more women-friendly public spaces by improving transportation or market places that meet the concerns and needs of women, even the most conservative ones, is important. Exposure to women in public spaces can increase their access to labour market information.

Involving children and adolescents of both sexes in the process of breaking discriminatory social norms passed down across generations is another effective strategy. The positive results of the Equity Movement in Schools program in India, Ethiopia, and Kenya are a successful example of norm changing [51].

The social norms and gender gap in LFP can be narrowed through vocational training to encourage women to enter male-dominated industries. Providing women-friendly, affordable, and practically useful training programs relevant to the labour market demands has shown positive results in developing countries [52].

\subsubsection{Eliminating Discriminatory Law and Gap in Legal Protection}

Society's expectations for gender roles are shaped by law. Hence, removing legal barriers is essential to promoting equal opportunities, treatment, and protection for women in the labour market. Eliminating restrictions on women's ability to get employment opportunities without husbands' permission, providing maternity and paternity leave, and ensuring gender equality in social protection benefits must be considered.

\subsubsection{Redistributing Unpaid Work and Care}

Investment in the redistribution of unpaid work has significant long-term benefits for women's economic empowerment, families, and the economy. Although gender division in unpaid work mainly depends on social norms and happens at the household level, government policy and private sector actions can play important roles. Local authorities should support easing the burden of childcare and elderly care by providing care services, mainly for children below age 6 and for the elderly.

\subsubsection{The Evolution of Women's Role in the Labour Force and the Achievement of SDGs}

The conditions affecting Iranian women's role in the country's labour force have steadily evolved over the 10 years covered in this study. While the progress towards full integration into the labour force, which is envisioned by SDG5 and SDG8, has been restrained by society's cultural and social norms along with discriminatory political forces, the conditions for substantial changes in the near future are evident. This study has empirically quantified these underlying changes that are affecting the labour force participation of women. The direction of these forces is pointing towards the increased future participation of women in the economic and social life of the country. These achievements have been clearly identified as key elements for the realisation of the social development goals as set out by the United Nations (2030 Agenda). 
National studies and an ILO 2018 report point to a large informal sector in Iran and a significant presence of women in the informal sector [53]. This study and most studies on Iran's FLFP and employment suffer from undertaking women in slum areas, new ruralurban migrants, and self-employed or family workers. Further study is needed to provide a comprehensive picture of the position of Iranian women in the labour market.

Author Contributions: Conceptualisation, E.T. and F.G.L.; empirical methodology, C.P. and E.T.; software, E.T. and C.P.; formal analysis, E.T.; investigation, E.T.; resources, E.T.; data curation, E.T.; writing—original draft preparation, E.T.; writing—review and editing, F.G.L.; supervision, F.G.L. and C.P. All authors have read and agreed to the published version of the manuscript.

Funding: This research received no external funding.

Institutional Review Board Statement: Not applicable.

Informed Consent Statement: Not applicable.

Data Availability Statement: The data that support the findings of this study are openly available in the Statistical Center of Iran at http:/ / amar.org.ir (accessed on 20 October 2021).

Conflicts of Interest: The authors declare no conflict of interest.

\section{References}

1. UN General Assembly. Transforming Our World: The 2030 Agenda for Sustainable Development. 21 October 2015. A/RES/70/1. Available online: https:/ / www.refworld.org/docid/57b6e3e44.html (accessed on 20 September 2021).

2. Klasen, S. What explains uneven female labor force participation levels and trends in developing countries? World Bank Res. Obs. 2019, 34, 161-197. [CrossRef]

3. Carriles Álvarez, A.; Beltrán-Godoy, J.H.; Mata Mata, L. The effect of women's identity and emancipative values in female labor force participation: A comparison between Latin American and OECD countries. Nova Sci. 2019, 11, 323-356. [CrossRef]

4. Aghajanian, A.; Vaezzade, S.; Kohan, J.A.; Thompson, V. Recent trends of marriage in Iran. Open Fam. Stud. J. 2018, 10, 1-8. [CrossRef]

5. Azadarmaki, T.; Bahar, M. Families in Iran: Changes, Challenges and Future. J. Comp. Fam. Stud. 2006, 37, 589-608. Available online: http:/ / www.jstor.org/stable/41604538 (accessed on 6 November 2020). [CrossRef]

6. Inglehart, R.; Haerpfer, C.; Moreno, A.; Welzel, C.; Kizilova, K.; Diez-Medrano, J.; Lagos, M.; Norris, P.; Ponarin, E.; Puranen, B.; et al. World Values Survey: Round Five-Country-Pooled Data File 2005-2009 Version. JD Systems Institute: Madrid, Spain, 2014. Available online: http:/ / www.worldvaluessurvey.org/WVSDocumentationWV5.jsp (accessed on 20 August 2019).

7. Inglehart, R.; Haerpfer, C.; Moreno, A.; Welzel, C.; Kizilova, K.; Diez-Medrano, J.; Lagos, M.; Norris, P.; Ponarin, E.; Puranen, B.; et al. World Values Survey: Round Six-Country-Pooled Data File 2017-2021 Version. JD Systems Institute: Madrid, Spain, 2014. Available online: https:/ / www.worldvaluessurvey.org/WVSDocumentationWV7.jsp (accessed on 20 August 2019).

8. Taheri, E.; Guven-Lisaniler, F. Gender Aspect of Economic Sanctions: Case Study of Women's Economic Rights in Iran. Available online: https: / ssrn.com/abstract=3303800 (accessed on 19 December 2018).

9. Koolaee, K. The impact of Iraq-Iran war on social roles of Iranian women. Middle East Crit. 2014, 23, 277-291. [CrossRef]

10. Becker, G.S. A Theory of the Allocation of Time. Econ. J. 1965, 75, 493-517. [CrossRef]

11. Mincer, J. Labour force participation of married women: A study of labour supply. In Aspects of Labour Economics; UniversitiesNational Bureau Committee for Economic Research Princeton University Press: Princeton, NJ, USA, 1962; pp. 63-105.

12. Hausman, J. Income and payroll tax policy and labor supply. In The Supply-Side Effects of Economic Policy; Mayer, L., Ed.; Center for the Study of American Business: St. Louis, MO, USA; Springer: Dordrecht, The Netherlands, 1981; Volume 63, pp. $173-202$.

13. Heckman, J.J. Effects of Childcare Programs on Women's Work Effort. J. Political Econ. 1974, 82, 136-163. Available online: http:/ / www.jstor.org/stable/1829997 (accessed on 26 October 2021). [CrossRef]

14. Schultz, V. Telling stories about women and work: Judicial interpretations of sex segregation in the workplace in Title VII cases raising the lack of interest argument. Harv. Law Rev. 1990, 103, 1749-1843. [CrossRef]

15. Assaad, R. Making sense of Arab labor markets: The enduring legacy of dualism. IZA J. Labor Dev. 2014, 3, 1-25. [CrossRef]

16. Hendy, R. A quarter century of changes in labor force participation. In Economic Research Forum Working Paper; $2015 ;$ p. 973. Available online: https:/ / erf.org.eg/app/uploads/2015/12/973.pdf (accessed on 6 October 2021).

17. Nazier, H.; Racha, R. Women's Participation in Labor Market in Egypt: Constraints and Opportunities. Middle East Dev. J. Forthcom. Econ. Res. Forum Work. Pap. 2016, 999. Available online: https://papers.ssrn.com/sol3/papers.cfm?abstract_id=3058316 (accessed on 6 October 2021).

18. Clark, R.; Ramsbey, T.W.; Adler, E.S. Culture, gender, and labor force participation: A cross-national study. Gend. Soc. 1991, 5, 47-66.

19. Inglehart, R.; Norris, P.; Ronald, I. Rising Tide: Gender Equality and Cultural Change Around the World; Cambridge University Press: Cambridge, UK, 2003; Volume 111, p. 226. 
20. Hayo, B.; Caris, T. Female labour force participation in the MENA region: The role of identity. Rev. Middle East Econ. Financ. 2013, 9, 271-292. [CrossRef]

21. Miles, R. Employment and unemployment in Jordan: The importance of the gender system. World Dev. 2002, 30, 413-427. [CrossRef]

22. Spierings, N.; Smits, J.; Verloo, M. Micro- and macrolevel determinants of women's employment in six Arab countries. J. Marriage Fam. 2010, 72, 1391-1407. [CrossRef]

23. Chamlou, N.; Muzi, S.; Ahmed, H. Understanding the determinants of female labor force participation in the Middle East and North Africa region: The role of education and social norms in Amman. Work. Pap. 2011, 31. Available online: https: //ideas.repec.org/p/laa/wpaper/31.html (accessed on 20 October 2021).

24. Diwan, I.; Vartanova, I. The effect of patriarchal culture on women's labor force participation. Cairi Egypt Econ. Res. Forum Work. Pap. 2017, 1110. Available online: https:/ / erf.org.eg/app/uploads/2017/05/1101.pdf (accessed on 20 October 2021).

25. Salehi-Esfahani, H.; Shajari, P. Gender, education, family structure, and the allocation of labour in Iran. Middle East Dev. J. 2012, 4, 1250008.

26. Bahramitash, R.; Esfahani, H.S. The transformation of female labour market. In Veiled Employment: Islamism and a Political Economy of Women's Employment in Iran; Bahramitash, R., Esfahani, H.S., Eds.; Syracuse University Press: New York, NY, USA, 2011; pp. 123-165.

27. Azimi, E. The effect of children on female labour force participation in urban Iran. IZA J. Labour Dev. 2015, 4, 5. [CrossRef]

28. Majbouri, M. Against the wind: Labour force participation of women and economic instability in Iran. Fem. Econ. 2016, 22, 31-53. [CrossRef]

29. Majbouri, M. Female labor force participation in Iran: A structural analysis. Rev. Middle East Econ. Financ. 2015, 11, 1-23. [CrossRef]

30. Mirzaie, I.A. Females' labour force participation and job opportunities in the Middle East. In Allied Social Science Association Annual Meeting Papers; Allied Social Science Association: Boston, MA, USA, 2015; pp. 3-5.

31. Goldin, C. The quiet revolution that transformed women's employment, education, and family. Am. Econ. Rev. 2006, 96, 1-21. [CrossRef]

32. Gündüz-Hoşgör, A.; Smits, J. Variation in labour market participation of married women in Turkey. Women's Stud. Int. Forum 2008, 31, 104-117. [CrossRef]

33. Moghadam, V.M. Towards Gender Equality in the Arab/Middle East Region: Islam, Culture, and Feminist Activism (No. HDOCPA-2004-06). Human Development Report Office (HDRO), United Nations Development Programme (UNDP). 2004. Available online: hdr.undp.org/sites/default/files/hdr2004_valentine_moghadam.pdf (accessed on 26 October 2021).

34. Hoodfar, H. Between Marriage and the Market: Intimate Politics and Survival in Cairo; Universitv of California Press: Berkeley, CA, USA, 1997; Volume 24, p. 104.

35. Majbouri, M. Oil, laws, and female labour force participation. Int. Adv. Econ. Res. 2017, 23, 91-106. [CrossRef]

36. Moghadam, V.M. Modernising Women: Gender and Social Change in the Middle East; Lynne Rienner Publishers: Boulder, CO, USA, 2003.

37. Moghadam, F.E. An evaluation of the productive performance of agribusinesses: An Iranian case study. Econ. Dev. Cult. Chang. 1985, 33, 755-776. [CrossRef]

38. Bahramitash, R.; Esfahani, H.S. Nimble fingers no longer! Women's employment in Iran. In Contemporary Iran: Economy, Society, Politics; Gheissari, A., Ed.; Oxford University Press: New York, NY, USA, 2009; pp. 77-122.

39. Shavarini, M.K. The feminisation of Iranian higher education. Int. Rev. Educ. 2005, 51, 329-347. [CrossRef]

40. Hägglund, A.E.; Bächmann, A.C. Fast lane or down the drain? Does the occupation held prior to unemployment shape the transition back to work? Res. Soc. Stratif. Mobil. 2017, 49, 32-46. [CrossRef]

41. Pampel, F.C.; Tanaka, K. Economic development and female labour force participation: A reconsideration. Soc. Forces 1986, 64, 599-619. [CrossRef]

42. Kian, A. Gendered occupation and women's status in post-revolutionary Iran. Middle East. Stud. 1995, 31, 407-421. [CrossRef]

43. Kian, A. Gender social relations and the challenge of women's employment. Middle East Crit. 2014, 23, 333-347. [CrossRef]

44. Groh, M.; McKenzie, D.; Shammout, N.; Vishwanath, T. Testing the importance of search frictions, matching, and reservation prestige through randomised experiments in Jordan. IZA J. Labor Econ. 2014, 4, 2-43.

45. Bergmann, B.R. The effect on white incomes of discrimination in employment. J. Political Econ. 1971, 79, 294-313. [CrossRef]

46. Anker, R. Theories of occupational segregation by sex: An overview. Int. Lab. Rev. 1997, 136, 315.

47. Khandan, A.; Nili, M. Government interventions and the size of the informal economy. The case of Iran (1971-2007). J. Econ. Policy Reform 2014, 17, 71-90. [CrossRef]

48. Bahramitash, R.; Esfahani, H.S. Gender and entrepreneurship in Iran. Middle East Crit. 2014, 23, 293-312. [CrossRef]

49. Equality, P.G. Building Support for Gender Equality among Young Adolescents in School: Findings from Mumbai, India. Int. Cent. Res. Women 2018. Available online: wojde.org/FileUpload/bs295854/File/04_24.pdf (accessed on 26 October 2021).

50. Sarfaraz, L. Women's Entrepreneurship in Iran; Springer: Cham, Switzerland, 2017.

51. Tautz, S. Youth to Youth Initiative: Assessment of Results in Ethiopia and Kenya; Deutsche Stiftung Weltbevoelkerung: Heidelberg, The Netherlands, 2011. 
52. Hicks, J.H.; Kremer, M.; Mbiti, I.; Miguel, E. Vocational Education Voucher Delivery and Labor Market Returns: A Randomised Evaluation among Kenyan Youth. Report for Spanish Impact Evaluation Fund (SIEF) Phase II. Available online: www.siteresources.worldbank.org/.../VocEd_SIEF_Report_2011-04-07_final (accessed on 26 October 2021).

53. Moghadam, F.E. Undercounting women's work in Iran. Iran. Stud. 2009, 42, 81-95. [CrossRef] 